\title{
Formation of Regional Tourism and Recreational Cluster
}

Fetisova Olga Vladimirovna

\author{
Kurchenkov Vladimir Viktorovich
}

Matina Elena Sergeevna

The Volgograd State University, 400062. Russia, Volgograd, pr. Universitetsky, 100

\section{Doi:10.5901/mjss.2015.v6n5s2p142}

\section{Abstract}

The goal of this article is to define tendencies of developing the tourism and recreational cluster of the Volgograd Region and explain promising directions of its development. In order to achieve the set goals, the following tasks were determined and subsequently solved: the actual state of tourism and recreational complex of the region was analyzed, factors of competitive ability of the tourism sector of economy in the Volgograd Region were revealed, the model of regional tourism and recreational cluster was developed, and strategic tasks and cluster projects aiming to solve them were defined. In order to implement the Strategy of developing the tourism cluster of the Volgograd Region, the author has developed a number of events that provide access to and receipt of the required resources for implementing cluster projects.

Keywords: tourism and recreational cluster (TRC), tourism infrastructure, natural and historical potential, recreational potential of the territory, cultural heritage, clusters identification.

\section{Introduction}

Tourism is an acknowledged driving force of economic growth. It has a strong potential for regional development and can become an efficient means for attracting resources to the region (Mariani, Buhalis, Longhi and Vitouladiti, 2014).

At the present time tourism industry takes up a conspicuous place in the strategy of social and economic development of subjects of the Russian Federation. In this context the tourism competition growth and formation of the strategy of its development is one of the key problems of regional management.

The competitiveness of the tourism sector can be described as a result of the interaction between natural and anthropogenic factors of tourist directions attractiveness. Above all, it is defined by the ability of travel companies to attract new visitors, form the quality of goods and services. The cluster approach is the most promising one in the development of tourism and provision of the region competitiveness (Shepelev and Markova, 2012).

The cluster theory was studied by many outstanding researchers, and depending on the researches direction they differently interpret the notion of cluster. $\mathrm{M}$. Porter is recognized as a founder of the cluster approach in economy. He defines the cluster as "a geographic concentration of interrelated companies and cooperating enterprises related to them and operating in a specific area that is characterized by common activity and mutual complementing of one another" (Porter, 2000, 25).

In tourism clusters are characterized as interrelated institutional objects on the limited territory that perform activity related to providing tourism and recreational services (Karmanova, Podsevalova, Zikirova, Silaeva and Leonova, 2015). Tourism and recreational clusters (TRC) include tour operators, hotels, air companies, guides, restaurants, and gift shops as well as suppliers, clients, labor force, governmental agencies, professional associations, research and educational institutes.

The economic activity related to it has a tendency to agglomeration due to a number of reasons including availability of unique natural resources, nearness to markets and decrease of transaction expenses.

The role of clusters as an important factor of competitiveness in the process of forming a regional tourism sector and various problems related to these aspects is a subject of various scientific researches (Malakauskaite \& Navickas, 2010).

In spite of the fact that the cluster form of creating the tourism and recreational complex of the region stipulates spontaneous and accidental character, there is some level of controllability while forming the cluster, its developing and functioning. It requires its methodological provision (Sangadiev \& Dondokov, 2010). Taking into account a rather broad 
acknowledgement of tourism in increasing the competitiveness of regional development, problems of strategic development of tourism and recreational clusters acquire special urgency.

The goal of this article is to analyze the state of the tourism and recreational cluster of the Volgograd Region and propose a conceptual model of its strategic development.

The tasks of the research include:

- To analyze urgent state of tourism in the Volgograd Region,

- To reveal factors of competitiveness of the tourism sector of economy in the Volgograd Region,

- To define possible forms and tendencies of the tourism and recreational cluster development.

\section{Methodology}

\subsection{Methodology of Forming a Model of Tourism and Recreational Cluster}

The necessity to study clusters and cluster systems in the tourism and recreational area stipulated the use of general scientific and special methods. General scientific methods include dialectic, abstract-logical analysis, expert evaluation method, dynamic and comparative analysis, management decisions synthesis, comparison and generalization, methods of economic systems analysis (shift analysis).

The proposed methodology of forming the model of tourism and recreational cluster of the Volgograd Region includes several stages that are schematically introduced on Figure 1.
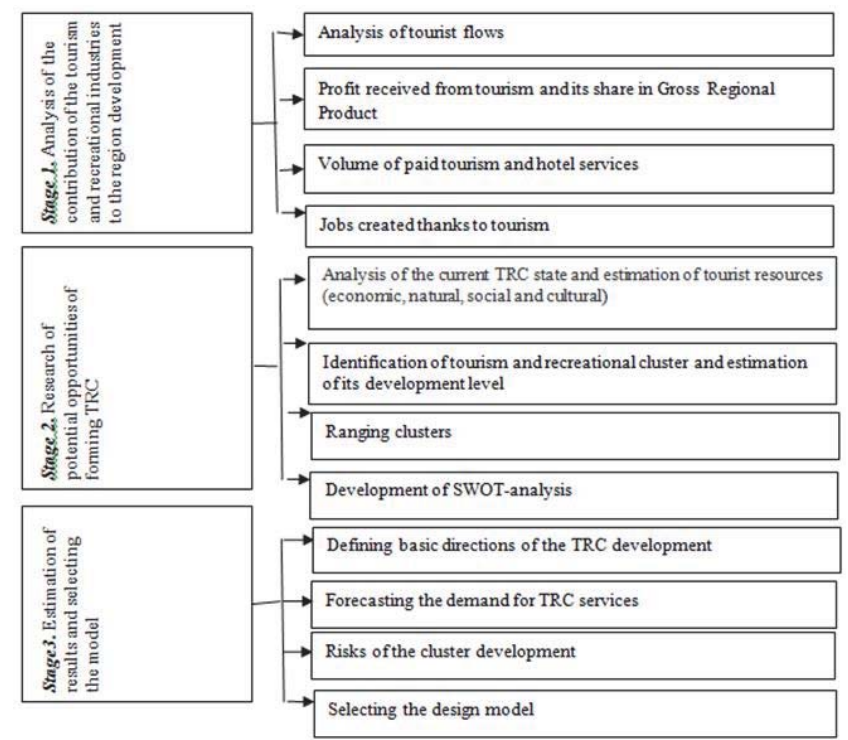

Figure 1. Methodology of Forming a Model of the Tourism and Recreational Cluster of the Volgograd Region

At the first stage it is necessary to make analysis of the contribution of tourism and recreational industry in the development of the region according to four criteria: evaluation of tourist flows with a breakdown into trips purposes, share of profits received from tourism in the Gross Regional Product (GRP), volume of the provided tourism and hotel services, employment in the tourism area.

At the second stage potential opportunities of forming a TRC including the evaluation of social and cultural, natural and ecologic and economic potential of the region under research are studied.

The availability of establishments of cultural and leisure type, theaters, museums, sanatorium-resort and sanitary institutions, hotels and similar forms of accommodation, conference halls, and exhibition centers etc. in the territory is a characteristic of social and cultural terms and conditions of forming and developing a TRC (Drozdetskaya, 2013).

Natural conditions of forming and developing a TRC can be characterized by the availability of natural parks, 
genuine significant sites, rivers and lakes.

Economic conditions of forming and developing a TRC can be characterized by such indicators as transportation infrastructure, state of manufacture and entrepreneurship.

For the purposes of the research official data of the Federal Service of State Statistics in the Volgograd Region, Federal Agency on Tourism of the Russian Federation, Committee of Economy of the Volgograd Region, Agency of Tourism Development in the Volgograd Region, Tourism and Information Center of the Volgograd Region was analyzed.

\subsection{Methods of Clusters Identification}

In order to reveal the role of the tourism and recreational cluster in the regional economy and for initial stage of clusters identification, the technics of structural changes analysis (SS) is applied. The structural changes analysis is a special selection of summary tabular data from a widely general set of descriptive statistical models. It requires a definite modification for the analysis of every specific situation and assumes the evaluation of three components hat influence the change of volumes of the industrial manufacture:

1) National component (NS) for the $i$ sector in the $r$ region in the $t$ year is defined as a part of a regional indicator (Qr) growth being proportional to the growth of the national-wide indicator (QN)according to the following formula (Mikheeva, 2013):

$N S_{i r}^{t}=Q_{i r}^{t-1} *\left(\frac{Q_{n}^{t}}{Q_{n}^{t-1}}-1\right),(1)$

2) The effect of the industrial composition (IM) defines the value of the growth of the regional indicator stipulated by the peculiarities of the industrial composition of the region: it displays the growth of the regional indicator if the regarded sector grew according to the tempo that corresponded to the one of the national economy:

$I M_{i r}^{t}=Q_{i r}^{t-1} *\left(\frac{Q_{i n}^{t}}{Q_{i n}^{t-1}}-\frac{Q_{n}^{t}}{Q_{n}^{t-1}}\right)$,

3) Regional shift component (RS) characterizes the difference between real and assumed growth if the regarded sector grew according to the tempo that corresponded to the nation-wide one in this sector:

$R S_{i r}^{t}=Q_{i r}^{t-1} *\left(\frac{Q_{i r}^{t}}{Q_{i r}^{t-1}}-\frac{Q_{i n}^{t}}{Q_{i n}^{t-1}}\right)$,

4) Joint shift of the regional indicator is defined as a sum of three introduced components (Karlina, 2011):

$N S_{i r}^{t}+I M_{i r}^{t}+R S_{i r}^{t}$

The tourism cluster is a quintessential geographically localized union of tourist enterprises which development is characterized by the agglomeration effect. The latter is expressed in the pursuance of geographic contingence (Nikituk, 2013). In order to identify clusters, it is necessary to define the peculiarities of tourism functioning in separate areas of the region. Such analysis is based on the calculation of three indicators that characterize the competitive stability of the tourism and recreational complex and potential of its clustering. They include coefficients of localization, specialization and manufacture by person.

\section{Results}

\subsection{Analysis of the Tourism and Recreational Branches Contribution to the Region Development}

The Volgograd Region is the Getaway Hub to the south of Russia. It occupies the south-eastern part of the Russian Plain; its area is 112.9 thous. sq. $\mathrm{m}$. hence through the neighboring Kazakhstan there is a way to India, and it is possible to reach Iran and Iraq by moving though the Caucuses. The region occupies the territory on the lower reaches of the great Russian rivers: Volga and Don. They are united by the Volga-Don Canal that gives access to seas ("Geopolitical Position of the Volgograd", http://www.investvolga.com/about_region/geopolitical_position).

The regional center is the city of Volgograd. It is a large administrative center where more than a million of persons live. $75 \%$ of the Volgograd Region population that is about 2.5 mil. persons live in cities (Volgogradstat, http://volgastat. gks.ru/wps/wcm/connect/rosstat_ts/volgastat/ru/statistics/population).

At the present time cultural and cognitive, children's and young people's, ecological, ethnographic, active, sanitary, religious, river, business and social tourism is developed in the territory of the Volgograd Region.

The nature of the Volgograd Region offers unique potential opportunities for the development of ecological tourism: in the territory of the region there are seven natural parks and numerous genuine significant sites, natural areas, dendrology objects, sanitary and recreational zones and resorts.

Cultural and historic potential of the region is made up by 1,164 historical and cultural monuments, 923 samples of 
architecture, more than 20 thousand of archeological objects.

There are 45 museums, 14 theatres, 375 establishments of cultural and leisure type, 69 sanatorium-resort and treatment establishments, 163 hotels and similar forms of accommodation in the region.

The Volgograd Region is one of the most attractive for foreign guests in the Southern Federal District and in Russia, as a whole. For the period of 2009-2013 the tourist flow increased by more than 5.5 times. The amount of people accommodated in hotels and similar forms of accommodation, sanatorium-resort establishments of the regions increased by $16 \%$ and was 349.1 thous. persons as compared to 2009. Most often the region is visited with business and professional (41.4\% in 2013 and 41.5\% in 2009) or leisure and rest goals (31.3\% in 2013 and 29.0\% in 2009).

The number of package tours sold to the population of the Volgograd Region increased by 4.9. times and reached 47.6 thous. ones according to the results of 2013. At the present time in the territory of the Volgograd Region there are 173 travel companies where 549 persons work. Basic indicators of the development of tourism in the Volgograd Region are shown in Table 1.

Table 1. Basic Indicators of the Development of Tourism in the Volgograd Region for 2009-2013 (Volgogradstat, 2014)

\begin{tabular}{|c|c|c|c|c|c|c|}
\hline Indicator & 2009 & 2010 & 2011 & 2012 & 2013 & Growth/fall, 2013/2009, \% \\
\hline Number of tourist firms, units & 57 & 65 & 151 & 148 & 173 & $303.5 \%$ \\
\hline Average amount of employees, persons & 211 & 323 & 497 & 506 & 549 & $260.2 \%$ \\
\hline Number of tourists that were serviced, persons & 13,742 & 40,117 & 55,171 & 65,908 & 75,703 & $550.9 \%$ \\
\hline Internal tourist flow & 7,871 & 19,039 & 19,811 & 23,564 & 25,897 & $329.0 \%$ \\
\hline Number of tour packages sold to the population, units & 9,702 & 26,417 & 29,999 & 40,870 & 47,582 & $490.4 \%$ \\
\hline $\begin{array}{l}\text { including } \\
\text { - in the territory of Russia, units }\end{array}$ & 6,189 & 13,881 & 10,658 & 16,193 & 19,946 & $322.3 \%$ \\
\hline - foreign countries, units & 3,513 & 12,536 & 19,341 & 24,677 & 27,636 & $786.7 \%$ \\
\hline $\begin{array}{l}\text { Number of persons accommodated in hotels and similar forms of } \\
\text { accommodation, thous. persons }\end{array}$ & 380.63 & 398.33 & 424.25 & 476.92 & 441.39 & $116.0 \%$ \\
\hline $\begin{array}{l}\text { Number of persons accommodated in hotels and similar forms of } \\
\text { accommodation, excluding micro enterprises, thous. persons }\end{array}$ & 296.6 & 314.5 & 348.5 & 367.9 & 349.1 & $117.7 \%$ \\
\hline $\begin{array}{l}\text { including according to purposes: } \\
\text { - vacation, leisure and rest, thous. persons }\end{array}$ & 86.1 & 105.4 & 107.4 & 126.3 & 109.2 & $126.8 \%$ \\
\hline - medical procedures and treatment & 39.6 & 35.7 & 38.5 & 36.1 & 36.9 & $93.2 \%$ \\
\hline - business and professional & 123.2 & 122 & 124.2 & 147.1 & 144.5 & $117.3 \%$ \\
\hline - miscellaneous & 47.7 & 51.4 & 78.4 & 58.4 & 58.5 & $122.6 \%$ \\
\hline
\end{tabular}

According to the results of 2013 the total contribution of tourism in the Gross Regional Product of the Volgograd Region was $0.8 \%$ (in 2009 this indicator was on the level of $0.5 \%$ ).

At the same time positive dynamics of the development of tourism in the Volgograd Region should not go unnoticed. The analysis of profits received from tourism for 2009-2013 is displayed in Table 2.

Table 2. Analysis of Profits from Tourism in the Volgograd Region for 2009-2013

\begin{tabular}{|l|c|c|c|c|c|c|}
\hline Indicator & 2009 & 2010 & 2011 & 2012 & 2013 & Growth/fall, 2013/2009, \% \\
\hline Gross Regional Product, mil. RUB & $377,514.3$ & $433,473.7$ & $508,433.3$ & 571,516 & 606,123 & $160.6 \%$ \\
\hline Volume of paid tourism services, mil. RUB & 859.4 & 659.6 & $1,459.8$ & $1,437.5$ & $3,539.4$ & $411.8 \%$ \\
\hline $\begin{array}{l}\text { Volume of paid services of hotels and similar forms of } \\
\text { accommodation, mil. RUB. }\end{array}$ & 862.3 & 779.4 & 899.7 & 982.4 & $1,136.1$ & $131.8 \%$ \\
\hline Cost of package tours sold to population, in total, mil. RUB & 248.58 & 759.23 & $1,314.46$ & $1,447.71$ & $1,731.51$ & $696.6 \%$ \\
\hline including in the territory of Russia, mil. RUB & 114.3 & 248.98 & 290.22 & 361.14 & 389.92 & $341.1 \%$ \\
\hline Foreign countries, mil. RUB & 134.29 & 510.25 & $1,024.24$ & $1,086.58$ & $1,341.59$ & $999.0 \%$ \\
\hline $\begin{array}{l}\text { Profits of collective forms of accommodation for all } \\
\text { operating subjects, mil. RUB }\end{array}$ & $1,230.2$ & $1,279.3$ & $1,458.5$ & $1,621.5$ & $1,767.5$ & $143.7 \%$ \\
\hline - including hotels & 629.3 & 640.2 & 726 & 808.7 & 920.6 & $146.3 \%$ \\
\hline
\end{tabular}

For five years the volume of profits received from paid tourist services increased more than 4 times. The volume of the paid services provided by hotels and similar forms of accommodation increased by $31.8 \%$.

Package tours to foreign countries in the amount of 1.3 bil. rubles were sold to the population. It is 10.0 times more as to the level of 2009. The total value of package tours sold to the population in 2013 was $1.7 \mathrm{bln}$. rubles ( 7.0 times more as compared to the level of 2009). 


\subsection{Results of Identifying Tourism Clusters of the Volgograd Region}

Structural changes in the employment of population according to economy branches for the period of 2009-2013 show the role of the tourism and recreational complex in the structure of the economy of the Volgograd Region (Table 3).

Table 3. Structural Changes in the Employment of Population in the Tourism and Recreation Area in the Volgograd Region for 2009-2013

\begin{tabular}{|c|c|c|c|c|}
\hline \multirow{2}{*}{ Indicator } & \multirow{2}{*}{2009} & \multirow{2}{*}{2013} & \multicolumn{2}{|c|}{ Change } \\
\hline & & & thous. RUB & $\%$ \\
\hline Number of employees in the tourism and hotel industry of the Volgograd Region, in total, thous. persons & 6.611 & 4.349 & -2.262 & $-34.2 \%$ \\
\hline Number of employees in the tourism and hotel industry of the Russian Federation, in total, thous. persons & 445.127 & 425.144 & -19.983 & $-4.5 \%$ \\
\hline Number of employees involved in the economy of the Russian Federation, thous. persons & $6,9410.5$ & $71,391.46$ & $1,981.00$ & $2.9 \%$ \\
\hline National component NS & \multicolumn{4}{|c|}{0.189} \\
\hline Sectoral structure outcome (IM) & \multicolumn{4}{|c|}{-0.485} \\
\hline Regional change component (RS) & \multicolumn{4}{|c|}{-1.965} \\
\hline Total structural change & \multicolumn{4}{|c|}{-2.262} \\
\hline
\end{tabular}

The analysis of the structural changes allowed to make the following conclusions about the peculiarities of developing tourism in the Volgograd Region:

- Tourism does not determine the region specialization(SS $<0)$,

- Tourism is a weak industry and is developed under unfavorable regional and industrial conditions $(\mathrm{IM}<0 ; \mathrm{RS}$ $<0)$

- Tourism is developed only due to national factors as SB national component (0.189) exceeds the indicator of RS regional component (-1.965).

The analysis of functional condition of the tourism and recreational complex of the Volgograd Region showed that at the present time in the territory of the complex conditions had been created for forming tourism and recreational clusters that correspond to the set criteria:

- Geographical concentration. Due to high concentration of enterprises in centers of the tourism and recreational service of the Volgograd Region conditions were created for saving on swift interaction that stems from the range of activity,

- Plurality of economic operators. The number of tourism and recreational enterprises in cities is as follows: Volgograd - 841 ones (62.5\% of the total number in the region), Volzhsky - 198 ones (14.7\%). Functioning of a many enterprises within one market space is sufficient for the emergence of competitiveness for manufacture factors and sales market,

- Specializations. Enterprises of local tourism and recreational clusters focus on satisfying cultural and cognitive, sanitary and recreational needs of visitors (Riabova \& Vypritskaya, 2014).

As a result of the conducted SWOT-analysis we have revealed the basic competitive advantages of the Volgograd Region as well as disadvantages that can turn into a real threat for stable development of the tourism and recreational complex of the region (Table 4).

Table 4. SWOT-analysis of the Tourism and Recreational Complex of the Volgograd Region

\begin{tabular}{|c|c|}
\hline Strengths & Weaknesses \\
\hline $\begin{array}{l}\text { Unique natural resources } \\
\text { Rich cultural and historical heritage } \\
\text { Rich recreational potential of the territory on the overflow land at } \\
\text { the Volga and Don rivers } \\
\text { Relative nearness to major tourism centers of the country } \\
\text { Well-developed transport infrastructure } \\
\text { Interest of the regional government in the development of an } \\
\text { innovation tourism complex }\end{array}$ & $\begin{array}{l}\text { Deficiency of attractive competitive tourism products } \\
\text { Low level of the tourism infrastructure development } \\
\text { Insufficient financing of programs related to the development of tourism and } \\
\text { recreational sector of economy } \\
\text { Complicated ecological position in Volgograd, Volzhskoe } \\
\text { Lack of a fully functional system of monitoring the development of tourism and } \\
\text { recreational complex in the region } \\
\text { Limited information about tourism products of the Volgograd Region } \\
\text { Unsatisfactory state of the larger part of historical and cultural heritage }\end{array}$ \\
\hline Opportunities & Threats \\
\hline $\begin{array}{l}\text { Perspective of developing tourism, recreation and treatment } \\
\text { Availability of dense populated localities situated closely to cities } \\
\text { and potential possibility to unite them in the Volgograd } \\
\text { agglomeration, }\end{array}$ & $\begin{array}{l}\text { Increasing competitiveness on the part of neighboring subjects of the Volgograd } \\
\text { Region, } \\
\text { Decreasing of financing the development of the assisting and transportation and } \\
\text { logistics infrastructure (including tours and objects of cultural heritage) related to }\end{array}$ \\
\hline
\end{tabular}




\begin{tabular}{|l|l|}
\hline Financing the tourism cluster in the territory of the Kaliningrad & federally owned objects. \\
Region by means of the federal budget provided for state capital & Impoverishment of fish and biological supplies and resources \\
investments as subsidies & $\begin{array}{l}\text { Deficiency of river tourism tours } \\
\text { "North-South" and "West-Eats" international transportation } \\
\text { Corridors through the Volgograd Region }\end{array}$ \\
$\begin{array}{l}\text { Providing high pressure of forms of accommodation due to } \\
\text { international and Russian online booking systems. }\end{array}$ & $\begin{array}{l}\text { quality service and safe terms and conditions of tourism with foreign customers } \\
\text { because of negative events related to foreign policy }\end{array}$ \\
\hline
\end{tabular}

Thus, the Volgograd Region has a god natural and historical potential that can become an accelerator of the tourism regional cluster development. In its turn, it will have a serious impact upon regional economy and cause the rally of branches associated with the tourism business.

At the same tie the existing potential threats that are external as a rule can have a negative impact upon the flow of tourists to the region and efficiency of the tourism and recreational complex of the region.

\subsection{Strategic Areas in the Development of Tourism and Recreational Complex of the Region}

The analysis of the current situation in the tourism and recreational complex of the Volgograd complex displayed that one of the major problems of its development was the lack of attractive competitive tourist product. In addition, even if there is a competitive tourist product, the lack of available information about it has a negative impact upon the development of tourism and recreational complex of the region.

The prevailing volume of the tourist product in the Volgograd Region (sightseeing tours, recreation and entertainment services, transportation and allocation services, souvenir gifts, etc.) has been formed yet in the Soviet period and consequently is morally out of date ("Draft of Strategy of Social and Economic Development", 2012). Today the tourist offer does not have a target character, and consequently it cannot equally meet the requirements of various categories of sophisticated tourists of the $21^{\text {st }}$ century. Comprehensive solution of this problem requires round financial injections in the development of infrastructure. However, there is an opportunity to partially solve this problem by conducting events related to communications, organizational and personnel work.

Unique natural, recreational resources and rich cultural and historic heritage of the Volgograd Region cannot be considered as the only and fully sufficient source for successful development of tourism. In view of insufficient development of the tourism infrastructure the current tourism and recreational potential of the Volgograd Region is not fully used. The majority of accommodation objects (hotels, hostels, sanatoriums, and camps) do not meet the world standards according to the level of service.

The following strategic tasks of the tourism and recreational complex can be regarded as principle:

- Contribution to the creation of a new tourist product and development of the current one in order to provide its competitiveness and correspondence to the needs of today's tourists.

- Forming the system of informing potential tourists and sellers of the tourist product (travel companies) about the tourist product and tourism infrastructure of the Volgograd Region, provide tourists with informational assistance during the preparation to rest and directly while staying in the territory of the region.

\subsection{Forming the Regional Tourism and Recreational Cluster}

It is possible to increase the efficiency of the tourism and recreational potential of the Volgograd Region by forming tourism clusters in the territory of the region.

The creation of tourism and recreational clusters is a problem of paramount importance because the Strategy of Social and Economic Development of the Volgograd Region up to 2025 C (The Law of the Volgograd Region "On Strategy of Social and Economic Development of the Volgograd Region up to 2025" of 21.11.2008 \#1778-OD) and Development of Internal and Incoming Tourism in the Volgograd Region for 2013 - 2017 Long-term Regional Target Program ("Resolution of the Government", 2013), aiming essential arrear is based on the cluster paradigm. Region.

Figure 1 displays a model of the tourism cluster that is a basis for its forming in the territory of the Volgograd 


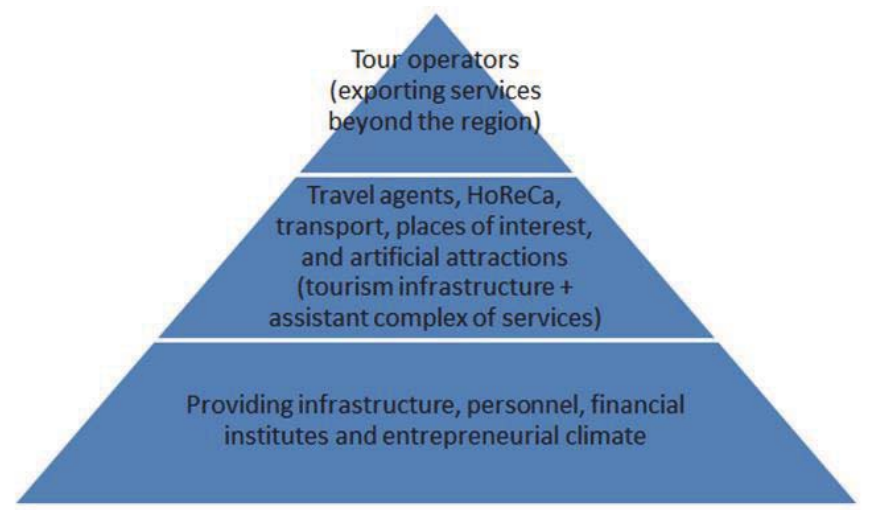

Figure 1. Model of Regional Tourism Cluster of the Volgograd Region

The task on establishing the Elton Balneological Complex tourism and recreational cluster situated in the Pallasovsk area was set within the program of tourism development. The goal of establishing the tourism and recreational cluster is to rationally use of natural health-giving resources of the Pallasovsk area and potential of the Elton natural park as well as to develop the resort tourism on their basis.

Within the program it is planned to establish a variety of objects of tourism purpose (tourist complexes, hotels, etc.) and objects of the assisting infrastructure (roads, power lines, berths, coast protection, etc.).

In addition, in the territory of the Volgograd Region it is planned to form a "Territory of Victories" tourism cluster that will combine the tourism infrastructure of Volgograd, Volzhsky and Kamyshin. The project was created for the tourist attractiveness of the region and full use of recreational potential of the Volga river basin.

It seems that it is possible to establish a lot of such clusters taking into account the tourism and recreational potential of the Volgograd Region. For example, it is possible to establish "Volzhskaya Venice" TRC that will use the tourism and recreational potential of the Volga and Akhtubinsk Poyma that is a natural park of the first category of the world importance (Fetisova, Kurchenkov and Matina, 2014).

In order to develop the tourism and recreational cluster in the Volgograd Region, diversify and strengthen advantages of the regional tourist product as well as to solve the tasks set for it, it is planned to accomplish the events introduced in Table 5.

Table 5. Tasks and Projects of the Cluster Development

\begin{tabular}{|l|l|}
\hline Task & Cluster projects aiming to solve the task \\
\hline Management of clusters development & $\begin{array}{l}\text { Project of organizational development of the cluster. } \\
\text { Organization of the consulting support of top-priority cluster projects }\end{array}$ \\
\hline $\begin{array}{l}\text { Strengthening partnership approaches within } \\
\text { the cluster development }\end{array}$ & Conduction of joint inter-regional and international projects \\
\hline $\begin{array}{l}\text { Development of tourism infrastructure and } \\
\text { forming terms and conditions for diversification } \\
\text { of the regional tourism product }\end{array}$ & $\begin{array}{l}\text { Providing the cluster members with state, municipal and other types of } \\
\text { support. } \\
\text { Projects on developing and implementing new tourism products }\end{array}$ \\
\hline $\begin{array}{l}\text { Implementation of the marketing strategy of } \\
\text { image promoting the region and tourism } \\
\text { products on the Russian and foreign markets }\end{array}$ & $\begin{array}{l}\text { Establishing of the regional tourism and informational center of the Volgograd } \\
\text { Region. } \\
\text { Annual marketing events related to promoting the cluster tourism products. }\end{array}$ \\
\hline
\end{tabular}

In order to implement the strategy of developing tourism clusters, it is necessary to attract both state and private investments. Herewith, the use of funds of federal target programs and funds of the regional budget must correspond to basic events and tasks of the strategy of social and economic development of the Volgograd Region.

In order to implement the Strategy of developing the tourism cluster of the Volgograd Region, the following events that provide access to and receipt of the resources required for implementing cluster projects must be planned:

- forming the composition of members of the Coordination Council of the cluster, 
- establishment of new enterprises and organizations to perform general activity and coordinate the cluster-wide interaction for separate functional areas - the coordination council of the cluster - by the cluster member enterprises and organizations,

- use and concentration of joint experience of performing works where it is assumed to implement investment projects and events within the development of the tourism cluster,

- designing business processes that are carried while implementing cluster-wide projects, establishing new enterprises and organizations of the tourism cluster. Use of best practices and scientific approach while designing organizations,

- concentration of financial resources of the cluster members for solving joint tasks (advertising and promoting the tourist product, implementation of investment projects, etc.),

- use of tax reliefs while locating enterprises in the tourism cluster in accordance with federal and regional law.

In addition to creating growth areas of tourism clusters, it is planned to actively develop other territories that do not enter clusters in the region. The implementation of projects of territories development and planned programs of clusters development will allow to provide stable development of the tourism and recreational complex, create the highly profitable complex of service in the area if tourism, rest and health care for guests and inhabitants of the Volgograd Region.

The implementation of projects related to forming tourism and recreational clusters will allow to receive a synergetic effect from the cooperation of enterprises entering it. It will be expressed in economic growth of clusters members and growth of their functioning efficiency. All members receive economic benefits and social effect that is expressed as the increase in the education level, growth of work places, improvement of social climate and receiving the budget effect due to the growth of the tax base.

\section{Acknowledgement}

The research was conducted with financial support of the Russian Foundation in the form of a grant for Humanities, project No. 15-12-34003.

\section{Conclusion}

Thus, the development of tourism and recreational territories on the basis of comprehensive development of the Regional tourism cluster is a primary measure of the Volgograd Region regional policy in the tourism development.

Herewith, it is necessary to broadly popularize tourist opportunities of the Volgograd Region and actively promote it as an attractive tourist destination both inside the country and abroad. In order to solve this task, it is necessary to achieve sufficient concurrence and interdependence of mechanisms of its implementation according to goals, tasks, methods, means, forms, priorities, stages and terms and conditions of their performance on all levels of economy (Fetisova \& Matina, 2012).

It is obvious that the union of activity areas and directions that are currently isolated in the regional tourist cluster will allow to achieve the synergetic effect in the industry and increase the Gross Domestic Product of the region.

\section{References}

Mariani M.M., D. Buhalis, Ch. Longhi and O. Vitouladiti, 2014.Managing change in tourism destinations: Key issues and current trends. Journal of Destination Marketing \& Management, January 2014: 269-272.

Shepelev, I.G. and Yu.A. Markova, 2012. Tourist and Recreational Clusters - Mechanism of Innovative Perfection of System of Strategic Management of Regions Development. Modern Research of Social Problems (scientific e-journal), 3(11). Date Views 20.02.2015 http://sisp.nkras.ru/e-ru/issues/2012/3/markova.pdf.

Porter, M., 2000. Location, Competition, and Economic Development: Local Clusters in a Global Economy. Economic Development Quarterly, Vol. 14, 1: 15-34.

Karmanova, T.E., E.N. Podsevalova, S.S. Zikirova, A.A. Silaeva and V.P. Leonova, 2015. Cluster Model of Regional Tourist Business in Russia. Asian Social Science, Vol. 11, 6: 279-286.

Malakauskaite, A. and V. Navickas, 2010. The role of clusters in the formation process of tourism sector competitiveness: conceptual novelties. Economics and Management, 15: 149-154.

Sangadiev, Z.G. and B.B. Dondokov, 2010. Strategy of Tourist and Recreational Cluster on the basis of Diversification-Oriented Region Development. In the Proceedings of the International Research-to-Practice Conference: Strategic Areas of Stable Development of the Baikal Region, Irkutsk, April 20-22, 2010, Chapter 2, pp: 7-11.

Drozdetskaya, A.A., 2013. Forming Tourist Clusters in Border Territories. Modern Problems of Science and Education, 2. Date Views: 
20.02.2015 www.science-education.ru/108-9132.

Mikheeva, N.N., 2013. Structural Factors of Regional Dynamics: Measure and Estimation. Spatial Economics, 1: 11-32.

Karlina, T.V., 2011. Identification of Regional Economic Clusters Nuclei on the basis of Analysis of Structural Shifts under Conditions of Cyclically Developing Economy. Bulletin of the Perm University, 4(11): 18-29.

Nikituk, D.V., 2013. Identification of Tourist Clusters (through the Example of the Brest Region) (Part 2). Land of Byelorussia. Recreational Geography Section, 1: 28-35.

Geopolitical Position of the Volgograd Region. Investment Portal of the Volgograd Region. Date Views 20.02.2015 http://www.invest volga.com/about region/geopolitical position.

Volgogradstat. Date Views 20.02.2015 http://volgastat.gks.ru/wps/wcm/connect/rosstat_ts/volgastat/ru/statistics/population.

Volgogradstat, 2014. Statistical Yearbook of the Volgograd Region 2013: Collection. Territory Body of the Federal Service of State Statistics in the Volgograd Region. Volgograd, pp: 838.

Riabova, L.V. and E.Yu.Vypritskaya, 2014. Forming Tourist Cluster (through example of the Volgograd Region). Economy and Management of Innovation Technologies, 11. Date Views: 20.02.2015 http://ekonomika.snauka.ru/2014/11/6232.

Draft of Strategy of Social and Economic Development of the Volgograd Region up to 2020. Date Views 20.02.2015 http://economics. volganet.ru/upload/iblock/bb6/PROEKT_STRATEGI20201.10.12.pdf.

The Law of the Volgograd Region "On Strategy of Social and Economic Development of the Volgograd Region up to 2025" of 21.11.2008 \#1778-OD.Official Portal of the Economy Committee of the Volgograd Region. Date Views 20.02.2015 http://economics.volganet.ru/upload/iblock/dbe/No1778-OD_ot_21.11.2008_red._ot_22.11.2013_doc.

Resolution of the Government of the Volgograd Region "On "Development of Internal and Incoming Tourism in the Volgograd Region" Long-term Regional Target Program" of 23.04.2013 \#188-P. Volgograd Pravda, 81 (08.05.2013).

Fetisova, O.V., V.V. Kurchenkov and E.S. Matina, 2014. Estimation of State of Tourist and Recreational Regional Complex While Forming its Development Strategy, Eds., Plotnikov, A.N. In the Proceedings of the V International Research-to-Practice Conference: Topical Issues of Developing Social and Economic Systems in Modern Society, November 6, 2014. Saratov: "Business Academy" TSPM Publishing House, pp: 168-174.

Fetisova, O.V. and E.S. Matina, 2012. Conceptual Provision of Strategy of Tourist and Recreational Development of Regional Complex.Finances.Economy. Strategy, 3(52): 39-45. 